\title{
Controlling long-range genomic interactions to reprogram the $\beta$-globin locus
}

\author{
Wulan Deng ${ }^{1,2}$, Jeremy W Rupon ${ }^{1}$, Hongxin Wang ${ }^{1}$, Andreas Reik ${ }^{3}$, Philip D Gregory ${ }^{3}$, Gerd A Blobel ${ }^{*}$ \\ From Epigenetics and Chromatin: Interactions and processes \\ Boston, MA, USA. 11-13 March 2013
}

Distal enhancers physically contact target promoters to confer high level transcription. At the mammalian $\beta$ globin loci long-range chromosomal interactions between a distal enhancer, called the locus control region (LCR), and the globin genes are developmentally dynamic such that the LCR loops to the embryonic, fetal and adult globin genes in a stage-appropriate fashion. LCR-globin gene interactions require the nuclear factor Ldb1. Recently, we employed artificial zinc finger (ZF) proteins to target Ldb1 to the endogenous $\beta$-globin locus to force an LCR-promoter loop. This led to substantial activation of $\beta$-globin transcription and suggested that forced chromatin looping could be employed as a powerful tool to manipulate gene expression in vivo (Deng et al., Cell 2012). Reactivation of the fetal globin genes in adult erythroid cells has been a long-standing goal in the treatment of patients with sickle cell anemia. Therefore, building on our findings, we investigated whether the developmentally silenced embryonic globin gene $\beta \mathrm{h} 1$ can be re-activated in adult murine erythroblasts by re-directing the LCR away from the adult type globin gene and towards its embryonic counterpart. To this end, Ldb1 was fused to artificial ZF proteins (ZFLdb1) designed to bind to the $\beta$ h 1 promoter. ZF-Ldb1 was introduced into definitive erythroid cells in which only the adult but not the embryonic $\beta$-like globin gene is expressed. In vivo binding of ZF-Ldb1 to its intended target was verified by chromatin immunoprecipitation assay. Strikingly, expression of ZF-Ldb1 re-activated $\beta$ h1 transcription up to approximately $\sim 24 \%$ of total cellular $\beta$-globin production. This suggests that forced tethering of a looping factor to a select promoter can be employed to override a pre-existing developmental long-range

'The Children's Hospital of Philadelphia, Hematology, Philadelphia, PA, 19104, USA

Full list of author information is available at the end of the article chromatin interaction to reprogram a developmentally controlled gene locus.

\section{Author details}

'The Children's Hospital of Philadelphia, Hematology, Philadelphia, PA, 19104, USA. ${ }^{2}$ University of Pennsylvania, Department of Biology, Philadelphia, PA, 19104, USA. ${ }^{3}$ Sangamo BioSciences, Inc, Richmond, CA, 94804, USA.

Published: 18 March 2013

doi:10.1186/1756-8935-6-S1-039

Cite this article as: Deng et al:: Controlling long-range genomic interactions to reprogram the $\beta$-globin locus. Epigenetics \& Chromatin 2013 6(Suppl 1):039.
Submit your next manuscript to BioMed Central and take full advantage of:

- Convenient online submission

- Thorough peer review

- No space constraints or color figure charges

- Immediate publication on acceptance

- Inclusion in PubMed, CAS, Scopus and Google Scholar

- Research which is freely available for redistribution

Submit your manuscript at www.biomedcentral.com/submit
C Biomed Central
() Biomed Central

(c) 2013 Deng et al; licensee BioMed Central Ltd. This is an Open Access article distributed under the terms of the Creative Commons Attribution License (http://creativecommons.org/licenses/by/2.0), which permits unrestricted use, distribution, and reproduction in any medium, provided the original work is properly cited. 